Professor Emeritus of Minerology at Harvard (C.S. Hurlbut) and the Curator Emeritus of Minerology at the Smithonion Institution (G.S. Switzer) is a selfconfessed "textbook" aimed at gemology courses as well as at jewellers and collectors. As such it is less readable tha Man-Made Gemstones; but it is much better as a work of reference - as well as being bigger (in number of pages and page

The book covers origin and occurrence of gemstones, crystal chemistry and crystllography, physical and optical properties of gems, gemological instruments, synthesis of gems, imitation gems, cutting and polishing. The longest chapter, "Descriptive Gemology", tabulates all the important features and size) and cheaper.

characteristics of the common gemstones (and some uncommon ones) with particular emphasis on how to tell whether the gem is natural, synthetic or imitation. There are also twelve full-page colour plates of superb quality.

These books are complementary, rather than being in direct competition; and both would make suitable presents for your favourite lapidary or jeweller, or for anyone with a scientific interest in gems and crystals. But if you can afford only one of them, Gemology is the bettery buy.

John Walker

John Walker was a Research Fellow at the Universities of Reading and Paris, studying the optical properties of diamond. He is currently a microprocessor consultant.

\section{Everything you wanted to know about cancer but were afraid to ask}

DISEASE has always haunted the human imagination. Leprosy, the black Death and other horrors have in turn stalked the misty frontiers of the collective unconscious. As the lethal epidemic diseases recede into history the archetypal phobias of Western Society are shifting their attention to cancer. One of civilisation's most awful self-inflicted wounds, cancer has become, like death itself, a taboo. In the third world the peasants flee to the hills when cholera strikes; in our affluent society there is nowhere to run to avoid what the late John Wayne called the big C. In the belief that fear can be abolished by knowledge (or rather, information) two recent books have been launched - from different directions and aimed at different audiences.

The Cancer Reference Book (Paddington: New York and London; £4.95), by P.M. Levitt and E.S. Gurabrick, is written by two American Professors of English using information provided by a small team of established cancer specialists. It is deliberately written in simple English, avoiding all technical language or complicated concepts. The style is light with quotations from Dylan Thomas, Robert Lowell et al, and it is rigorously honest. There is no obfuscation, no undue optimism. If a

- In the review of Malignant Neglect (see Nature, 282, 166; 1979), the first sentence of the second paragraph should have read: "A normal metabolite, ammonia, is called (page 105) a "toxic organic vapor"'," treatment does not work, the book says so. Reassurance is offered only when justified. It provides brief descriptions of the various forms of cancer and provides lists of questions and answers. The questions are real - the sort of questions asked by patients and their relatives. The information provided is strictly limited to topics of immediate relevance to patients with malignant disease and to the uninformed general public. Symptoms, treatments, prognosis and terminal care are well covered. The long section on widespread cancer and terminal care is very well presented and pays an envious tribute to the British hospice movement. Some aspects of the dialectic are (at present) peculiar to North America. Unproven treatment methods such as laetrile and the orgone box receive a lot of critical attention and furthermore the authors recommend that all men over 50 year. They also deal with "cancer insurance" in some detail, as in the USA 2 million such policies are sold every year. The cost of treatment for breast cancer can be as high as $\$ 100,000$ per patient.

Assuming that the reader knows absolutely nothing, the book contains simple line drawings most of which are probably helpful. However, one picture of the mouth labelled "the mouth" seemed just a little superfluous. However, this volume cannot really be judged by doctors. It is for the general public and for patients. To assess its value I have just completed a small uncontrolled trial by inviting questions from patients, relatives and friends. Each and every question was answered, and answered well, although finding them by referring to the index was a little frustrating at times. The Cancer Reference Book contains, as advertised in its subtitle "Direct and clear answers to everyone's questions". It must therefore be judged a considerable success. Its honesty will I suspect upset some doctors more than their patients. It could make life a little difficult for those, who, with should have a rectal examination once a euphemisms and woolly reassurance, use deception as a form of therapy. The Cancer Reference Book could be a blow for patient's lib.

Cancer: the Outlaw Cell is an edited collection, by R.E. La Fond, of articles originally published in Chemistry and now dressed up and issued by the American Chemical Society (Washington DC; \$15). It is a distinctly upmarket product. Written originally for chemists (no, not pharmacists) it now seems to be addressed to what I can only describe as " $\mathrm{a} \mathrm{BBC} 2$ audience"'. Expensively produced and beautifully illustrated its approach is conventional but slick (witness the title). Clinically it is uninformative and contains little or nothing about what cancer is or what it does to people. It is essentially a basic primer in some current trends in cancer research, very basic in places. An introduction to cell chemistry, for example, takes less than a page and a half. There are, however, some excellent general essays. Dr Armin C. Braun's chapter on cancer as a problem in development will fascinate anyone with an $O$ level in biology. There are also comprehensive chapters on chemical carcinogens, oncogenic viruses, the cell surface and the inevitable immunology.

A simple but concise essay on cancer chemotherapy by the Drs Burchenal highlights a central issue in contemporary cancer research. The logical approach to finding new drugs, they say, would be to find differences between normal and malignant cells and then exploit the difference. However, as this approach has been tried in the past and failed, it has been replaced almost totally by empirical drug screening, looking for antiproliferative agents, agents which by definition, are bound to be toxic. To illustrate the current obsession with "multi-modality therapy" they provide an unfortunate analogy. The body, they say, is like a lawn, normal cells are grass and cancer cells are weeds. Surgery is therefore the equivalent of hand weeding, radiotherapy is a flamegun and chemotherapy is (or should be) a selective weedkiller. Stimulation of the immune response is the equivalent of stimulating the grass to choke the weeks. As they put it so succinctly, immunotherapy is fertiliser.

It is an optimistic book, the authors of each chapter arguing strongly for their own line of research and its potential value. It is an excellent bit of public relations for American cancer research; no room here for self-doubt, for the currently fashionable pessimism. As an introduction to cancer for the scientifically literate layman it could make a fascinating read.

G.A. Currie

G. A. Currie is Reader in Tumour Immunology at the Institute of Cancer Research, and Honorary Consultant Physician at the Royal Marsden Hospital, Sutton, UK. 